Diabetologia 10, 205-209 (1974)

(C) by Springer-Verlag 1974

\title{
The Effect of Maternal Diabetes on Adipose Tissue Cellularity in Man and Rat
}

\author{
P. Björntorp, G. Enzi, K. Karlsson, M. Krotkiewski, L. Sjöström and U. Smith \\ Clinical Metabolic Laboratory of the First Medical Service, the Second Medical Service and the Departments of Gyne- \\ cology and Medical Rehabilitation, University of Gothenburg, Sahlgren's Hospital, Gothenburg, Sweden
}

Received: September 28, 1973, and in revised form: February 11, 1974

Summary. It is well recognised that the newborn of diabetic mothers may be overweight and obese, presumably due to excessive glucose and insulin levels in the fetus. Since recent evidence indicates that the number of fat cells is established early in life, we studied the effect of intrauterine hyperglycaemia and hyperinsulinaemia on adipose tissue cellularity. Six men (age range $21-26$ years) and six women (age range $18-24$ years) were investigated. Their weights at birth generally exceeded the average value by $2 \mathrm{~S}$.D. As a group they were not obese at the time of the investigation and neither total number of fat cells, average cell size nor body fat differed significantly from controls of the same age. There was no correlation between the number of fat cells and the weight at birth. The adipose tissue cellularity in the offspring of alloxan-diabetic rats (AX) and in controls (C) of oqual weight was also studied. When sacrificed (after 40 days) body weights and the weights of the epididymal and retroperitoneal fat pads were similar in the $A X$ and $C$ groups. However, the number of fat cells of the retroperitoneal fat pad was significantly increased in the AX group, while the cell size was slightly diminished. Cell data of the epididymal fat pads were not significantly different. The results indicate that excessive glueose and insulin levels in utero may influence the number of fat cells, but, in man, they do not seem to lead to a permanent hyperplasia of the adipose tissue.

Key words: Diabetes, adipose tissue, alloxan, cell size, cell number.
The expanded adipose tissue in obesity may be due either to an increased number of fat cells or to an enlargement of the adipocytes. The factors that control the proliferation and enlargement of the adipocytes are incompletely known. It is important, however, to elucidate these factors since the number of fat cells is of importance for the amount of body fat in adults $[1,2]$. Recent evidence indicates that the number of fat cells is established early in life in man [3] as well as in the rat [4]. It has been shown that dietary manipulations within the first few weeks of life may influence the number of fat cells in adults, while a similar experience at a later date only affects the cell size [1]. It seems, however, that it may be possible to influence the number of fat cells in adult animals by fat-feeding [5] or cold-adaptation [6].

Since excessive insulin levels often accompany obesity [7] this hormone may be one factor which stimulates the proliferation of the adipocytes, as also suggested by Kazdova and Vrana [8]. Available data show, however, that administration of insulin to the adult rat [9], or at birth [10], mainly affects the size rather than the number of fat cells. However, for reasons discussed above, it may well be that hyperinsulinaemia produced at an earlier date (in utero) does influence the cellularity of the adipose tissue. This concept is supported by the well established fact that offspring of alloxan diabetic rats $[11,12]$, as well as the children of diabetic mothers [13], are overweight and obese. In the present study the adipose tissue cellularity of these two conditions was investigated.

\section{Material and Methods}

\section{Children of Diabetic Mothers}

Six men (age range $21-26$ years) and six women (age range 18-24 years) were studied. Their mothers suffered from an inadequately treated insulin-dependent diabetes during the pregnancy. No preselection of the subjects was performed. Some clinical data at the time of the study are shown in Table 1. The birth weights exceeded the average value [14] by one SD in two cases (HE and SE) and in the rest of the group by two SD. Fasting venous blood samples were drawn for the determination of insulin [15], glucose [16], cholesterol [17], and triglycerides [18]. Weight and height were recorded. Body cell mass was calculated from body potassium, as described by Moore et al. [19]. Body potassium was determined with a whole body counter detecting naturally occurring ${ }^{40} \mathrm{~K}$ [20]. Total body water was measured by administration of tritiated water [21]; body fat was then calculated as described by Berg and Isaksson [22]. Mean adipose cell size was determined, as previously described [23], on percutaneous needle biopsies [24] obtained from the subcutaneous adipose tissue of four regions: 1. epigastric region; in the angle between the costal ares $3 \mathrm{~cm}$ below the sternum, 2. hypogastric region; at a point one third of a line between the superior iliac spine and the umbilicus, 3. gluteal region; the upper lateral quadrant of the gluteal region, and 4 . femoral region; at a point on the ventral side of the thigh one third of a line from the patella to the superior iliac spine. The average fat 
cell weight of these four regions was calculated and the body fat divided by this value to obtain an estimate of the total number of fat cells.

The results obtained were compared with controls, 22 men (age range 22-26 years) and 21 women (age range $20-27$ years), who had been investigated in the same way. The clinical data relating to most of the controls has been described in detail previously [25, 26]. In the female control group, unpublished data from eleven young (age range 20-27 years) healthy women were included. Although not randomly selected the controls were chosen in such a way that the weight index was within $\pm 20 \%$ of an established standard valid for Scandinavian men and women [27].

\section{Alloxan Diabetic Rats $(A x)$}

Alloxan diabetes was produced in 25 pregnant rats of the Sprague-Dawley strain, weighing $260-280 \mathrm{~g}$, by subcutaneous injection of alloxan monohydrate
Weight was measured periodically until 40 days after birth all young rats were killed by decapitation. Blood samples were collected for glucose determination [16] from the carotid vessels. Twenty rats from diabetic mothers (AX group) and 20 controls (C group) were used as weight matched pairs for further study.

The right epididymal fat pad was carefully cut off at the edge of the epididymis. Perirenal adipose tissue was removed from the right side between the inguinal region, the mid-line and the diaphragm. Wet weight was determined on a torsion balance, and then pieces of adipose tissue were collected for the determination of the triglyceride content [18] and for cell counting from standardized locations on the base of the epididymal fat pad, distal to the vessels and on the central part of the perirenal fat pad. Fat cell size was determined as described above [23]. Fat cell number was calculated from the average fat cell weight and the triglyceride content of the tissue.

Table 1. Clinical and metabolic data of the investigated children of diabetic mothers. (Mean $\leq S D$ )

\begin{tabular}{|c|c|c|c|c|c|c|c|c|c|}
\hline Subject & Sex & $\begin{array}{l}\text { Age } \\
\text { (yrs) }\end{array}$ & $\begin{array}{l}\text { Height } \\
\text { (cm) }\end{array}$ & $\begin{array}{l}\text { Weight } \\
\text { (kg) }\end{array}$ & $\begin{array}{l}\text { Weight } \\
\text { index }\end{array}$ & $\begin{array}{l}\text { Triglycerides } \\
(\mathrm{mM})\end{array}$ & $\begin{array}{l}\text { Cholesterol } \\
(\mathrm{mg} / 100 \mathrm{ml})\end{array}$ & $\begin{array}{l}\text { Blood glucose } \\
(\mathrm{mg} / 100 \mathrm{ml})\end{array}$ & $\begin{array}{l}\text { Insulin } \\
(\mu \mathrm{U} / \mathrm{ml})\end{array}$ \\
\hline SE & M & 25 & 174 & 68.0 & 0.98 & 0.73 & 220 & 78 & 8 \\
\hline $\mathrm{SB}$ & $\mathbf{M}$ & 21 & 190 & 76.0 & 0.94 & 0.68 & 183 & 56 & 8 \\
\hline $\mathrm{PH}$ & $\mathbf{M}$ & 21 & 173 & 69.0 & 1.01 & 0.89 & 243 & 69 & 11 \\
\hline OL & M & 23 & 177 & 71.0 & 0.99 & 0.51 & 187 & 65 & 8 \\
\hline BO & M & 26 & 172 & 90.0 & 1.32 & 1.01 & 215 & 75 & 12 \\
\hline $\mathrm{HE}$ & $\mathbf{M}$ & 23 & 176 & 85.0 & 1.20 & 0.90 & 173 & 87 & 12 \\
\hline Mean: & & $23 \pm 2$ & $177 \pm 7$ & $76.5 \pm 9.1$ & $1.07 \pm 0.15$ & $0.79 \pm 0.18$ & $204 \pm 27$ & $72 \pm 11$ & $10 \pm 2$ \\
\hline MP & $F$ & 20 & 175 & 57.0 & 0.82 & 0.66 & 248 & 70 & 8 \\
\hline $\mathrm{UN}^{-}$ & $\mathbf{F}$ & 24 & 171 & 67.0 & 1.01 & 0.36 & 154 & 72 & 10 \\
\hline $\mathrm{EA}$ & $\bar{F}$ & 18 & 169 & 53.0 & 0.81 & 0.47 & 201 & 65 & 8 \\
\hline LG & $\mathrm{F}$ & 23 & 162 & 50.0 & 0.83 & 0.56 & 187 & 56 & 8 \\
\hline IN & $\mathbf{F}$ & 20 & 169 & 71.0 & 1.09 & 1.09 & 178 & 76 & 10 \\
\hline $\mathrm{KA}$ & $\mathbf{F}$ & 18 & 170 & 72.0 & 1.09 & 0.48 & 150 & 69 & 8 \\
\hline Mean: & & $21 \pm 3$ & $169 \pm 4$ & $61.7 \pm 9.5$ & $0.94 \pm 0.14$ & $0.60 \pm 0.26$ & $186 \pm 36$ & $68 \pm 7$ & $9 \pm 1$ \\
\hline
\end{tabular}

a Calculated from the data of Lindberg et al. (27)

(Fluka, West Germany) on the eleventh or twelfth day of pregnancy. Alloxan was dissolved in physiological saline and given in a dose of $0.110 \mathrm{mg}$ per $\mathrm{g}$ body weight, as a freshly prepared $5 \%$ solution.

Diabetes was considered present when there was constant glucosuria, tested with a commercial teststrip. Gross hyperglycaemia was also found when the mothers were sacrificed. Fifteen pregnant, non-injected rats of the same strain and weight served as controls.

All animals in each group were housed in a single cage, having unlimited access to water and a commercial chow, containing by weight $5 \%$ fat, $55 \%$ carbohydrate, $23 \%$ protein and salts and vitamins (EWOS, Södertälje, Sweden). Immediately after delivery the litters were removed from the mothers. The two heaviest male new-born (weight exceeding $5.3 \mathrm{~g}$ ) in each litter were then selected and placed with a control mother, who thus had a litter of four.

\section{Results}

Children of Diabetic Mothers (CDM)

As a group the children of diabetic mothers (CDM) were not obese at the time of the investigation. Only in one case (BO) did the weight index exceed 1.2 (Table 1). All metabolic parameters studied, including fasting glucose and insulin levels, were within the normal range. The data on adipose tissue cellularity are shown in Table 2 . Neither body fat, average cell size nor total number of fat cells differed significantly from the controls. Regression analysis showed that there was no significant correlation between the weight at birth and the number of fat cells.

\section{Alloxan Diabetic Rats ( $A X)$}

There was no significant difference between the duration of pregnancy in the $\mathrm{C}$ group and $\mathrm{AX}$ group $(24.2 \pm 0.2$ and $24.7 \pm 0.3$, means $\pm \mathrm{SEM}$, respective- 
ly). Due to the preselection, the body weights of the $\mathrm{AX}$ and $\mathrm{C}$ groups were similar at birth, as was the weight increase during the following 40 days (Fig. 1). When sacrificed the average body weights were $167 \pm$ $5 \mathrm{~g}$ and $173 \pm 4 \mathrm{~g}( \pm \mathrm{SEM})$, respectively. Blood glucose at the 40 th day was not significantly different between the $\mathrm{AX}$ and $\mathrm{C}$ groups $(113 \pm 9$ and $110 \pm 5$, means \pm SEM, respectively). Table 3 shows the fat cell data for

Table 2. Adipose tissue cellularity in the children of diabetic mothers (CDM) and in the controls $(C)$. (Means $\pm S D)$

\begin{tabular}{|c|c|c|c|c|}
\hline & & $\begin{array}{l}\text { Body fat } \\
(\mathrm{kg})\end{array}$ & $\begin{array}{l}\text { Mean fat cell } \\
\text { weight of the } \\
\text { four regions } \\
(\mu g)\end{array}$ & $\begin{array}{l}\text { Average total } \\
\text { fat cell } \\
\text { number } \\
\left(\mathrm{n} \times 10^{-10}\right)\end{array}$ \\
\hline \multirow{2}{*}{ C } & $\begin{array}{l}\text { Males } \\
(n=22)\end{array}$ & $9.1 \pm 5.7$ & $0.36 \pm 0.13$ & $2.4 \pm 1.1$ \\
\hline & $\begin{array}{l}\text { Females } \\
(\mathrm{n}=21)\end{array}$ & $11.1 \pm 4.2$ & $0.34 \pm 0.07$ & $3.6 \pm 1.8$ \\
\hline \multirow{2}{*}{ CDM } & $\begin{array}{l}\text { Males } \\
(\mathrm{n}=6)\end{array}$ & $12.2 \pm 10.8$ & $0.35 \pm 0.14$ & $2.7 \pm 1.9$ \\
\hline & $\begin{array}{l}\text { Females } \\
(n=6)\end{array}$ & $8.0 \pm 4.5$ & $0.33 \pm 0.05$ & $2.5 \pm 1.5$ \\
\hline
\end{tabular}

Statistical analyses of the differences in means between the $\mathrm{C}$ and CDM did not reach significant levels for any variable neither in the males nor in the females $(p>$ $0.1)$.

\section{Discussion}

Excessive insulin levels and obesity are often associated [7]. Furthermore, offspring of alloxan diabetic rats $[11,12]$ and children of diabetic mothers [13] are frequently overweight and obese. The increased adiposity in these two conditions is presumably due to excessive fetal insulin and glucose levels, induced by the

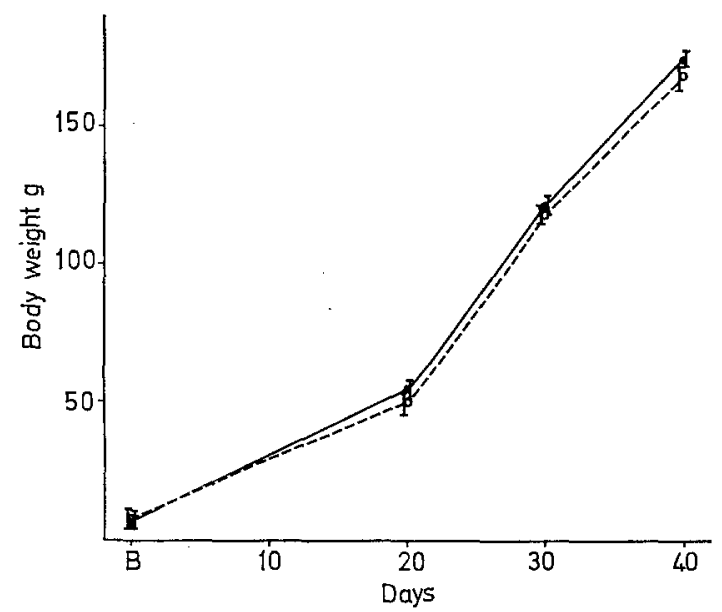

Fig. 1. Increase in body weight in the offspring of alloxandiabetic mothers (O) and in the controls (๑). Results \pm S.E.M.

Table 3. Fat cell size and number in the right epididymal and retroperitoneal fat pad of offspring of alloxan-diabetic rats and the controls

\begin{tabular}{lllll}
\hline & \multicolumn{4}{l}{ Epididymal fat } \\
\cline { 2 - 5 } & $\begin{array}{l}\text { Wet weight } \\
(\mathrm{mg})\end{array}$ & $\begin{array}{l}\text { Triglyceride } \\
\text { weight }(\mathrm{mg})\end{array}$ & $\begin{array}{l}\text { Average fat } \\
\text { cell weight }(\mu \mathrm{g})\end{array}$ & $\begin{array}{l}\text { Average fat cell } \\
\text { number }\left(\mathrm{n} \times \mathbf{1 0}^{-6}\right)\end{array}$ \\
\hline $\begin{array}{l}\text { Control group } \\
(\mathrm{n}=20)\end{array}$ & $\mathbf{5 8 5} \pm 85$ & $450 \pm 101$ & $0.13 \pm 0.02$ & $3.5 \pm 0.9$ \\
$\begin{array}{l}\text { Alloxan group } \\
(\mathrm{n}=20)\end{array}$ & $594 \pm 103$ & $450 \pm 81$ & $0.12 \pm 0.02$ & $3.8 \pm 0.9$
\end{tabular}

Retroperitoneal fat

\begin{tabular}{lllll} 
& $\begin{array}{l}\text { Wet weight } \\
(\mathrm{mg})\end{array}$ & $\begin{array}{l}\text { Triglyceride } \\
\text { weight }(\mathrm{mg})\end{array}$ & $\begin{array}{l}\text { Average fat } \\
\text { cell weight }(\mu \mathrm{g})\end{array}$ & $\begin{array}{l}\text { Average fat cell } \\
\text { number }\left(\mathrm{n} \times 10^{-6}\right)\end{array}$ \\
\hline $\begin{array}{l}\text { Control group } \\
(\mathrm{n}=20)\end{array}$ & $379 \pm 76$ & $303 \pm 94$ & $0.16 \pm 0.04$ & $1.9 \pm 0.9$ \\
$\begin{array}{l}\text { Alloxan group } \\
(\mathrm{n}=20)\end{array}$ & $408 \pm 117$ & $313 \pm 95$ & $0.13 \pm 0.04^{\mathrm{a}}$ & $2.4 \pm 0.4^{\mathrm{a}}$ \\
\hline
\end{tabular}

Means \pm S.D. a indicates significant difference between the groups $(p<0.05)$

the retroperitoneal and epididymal fat pads. There were no significant differences in the adipose tissue data from the epididymal fat pads between the AX and $\mathrm{C}$ groups, although the average number of fat cells was slightly increased in the alloxan group $(p<0.10)$. The retroperitoneal fat pads did not differ in weight, while the number of fat cells of the $\mathrm{AX}$ group was significantly increased and fat cell size slightly reduced. maternal hyperglycaemia [28]. It has previously been shown that administration of insulin to the adult rat [9] or after birth [10] mainly increases the cell size rather than the number of fat cells. However, available data suggest that the earlier the change in the nutritional level the more pronounced the effect $[1,3]$. Thus, the data reported by Brook [3] indicate that malnutrition in utero may lead to a permanent decrease in the 
number of fat cells; in a recent study we were unable to find this in subjects whose malnutrition started immediately after birth [29].

In the present study the total number of fat cells was estimated by dividing body fat with the average, mean fat cell size of the four subcutaneous sites studied. Justification for only using subcutaneous fat cell size for the calculations is drawn from Goldrick and MeLoughlin [30], who found a highly significant correlation between the size of subcutaneous and omental cells. Also, Sjöström [31] has shown that the femoral, abdominal and gluteal subcutaneous fat cell sizes are correlated. Accordingly, it seems that a fair estimate of the average mean fat cell size and, thus, fat cell number may be obtained by the technique used.

The present study comprises twelve children of diabetic mothers, who presumably had excessive fetal glucose and insulin levels, since in most cases their weights at birth exceeded the average value [14] by two SD. However, at the time of the study, they had neither increased amounts of body fat nor an increased number or size of the fat cells. Furthermore, regression analysis revealed that there was no correlation between the weight at birth and the adult number of fat cells. It may thus be that excessive fetal glucose and insulin levels do not influence the cellularity of the adipose tissue or that the differences at birth had disappeared. during the postnatal development of the adipose tissue. The first possibility seems rather unlikely in view of Knittle and Hirsch's [1] finding that early dietary manipulations may influence the number of fat cells.

Since it was, for practical reasons, not possible to investigate the children of diabetic mothers at an early age, studies were carried out with the offspring of alloxan diabetic rats. Only the offspring with a body weight exceeding $5.30 \mathrm{~g}$ were used, since it has previously been shown [11] that, at this weight, the newborn are characterized by increased body fat, compared with control rats of equal weight. The weight increase and the body weights of the $\mathrm{AX}$ and $\mathrm{C}$ groups were similar throughout the study. It had, of course, been advantageous to determine the cellularity immediately after birth, but this was found, in preliminary experiments, to be impossible, since the fat cells were too small to allow accurate determinations.

When sacrificed (after 40 days), the weights of the epididymal and retroperitoneal fat pads were similar in the AX and C groups. However, the cellularity of the retroperitoneal fat pad was significantly increased in the AX group, while the cell size was slightly decreased. Similar, but less pronounced, differences were obtained in the epididymal fat pads. Thus, it seems that excessive glucose and insulin levels produced at an early date may increase the number of fat cells in the rat. It seems reasonable to assume that a similar effect of intrauterine "over-feeding" is exerted in man. However, the ability of excessive glucose and insulin levels to induce a hypercellularity seems rather limited.
Acknowledgements. This study was supported by grant number B74-19X-251-12C from the Swedish Medical Research Council.

\section{References}

1. Knittle, J.L., Hirsch, J.: Effect of early nutrition on the development of rat epididymal fat pads: Cellularity and metabolism. J. clin. Invest. 47, 2091-2098 (1968)

2. Björntorp, P., Sjöström, L.: The number and size of adipose tissue fat cells in relation to metabolism in human obesity. Metabolism 20, 703-713 (1971)

3. Brook, C.G.D.: Evidence for a sensitive period in adipose-cell replication in man. Lancet 1972 II, 624627

4. Hirsch, J., Han, P.W.: Cellularity of rat adipose tissue: Effects of growth, starvation, and obesity. J. Lipid Res. 10, 77-82 (1969)

5. Lemonnier, D.: Effect of age, sex, and site on the cellularity of the adipose tissue in mice and rats rendered obese by a high-fat diet. J. elin. Invest. 51, $2907-2915$ (1972)

6. Therriault, D.G., Mellin, D.B.: Cellularity of adipose tissue in cold-exposed rats and the calorigenic effect of norepinephrine. Lipids 6, 486-491 (1971)

7. Karam, J.H., Grodsky, G.M., Forsham, P.H.: Excessive insulin response to glucose in obese subjects as measured by immunochemical assay. Diabetes 12, 197-204 (1963)

8. Kazdova, L., Vrana, A.: Insulin and adipose tissue cellularity. Horm. Metab. Res. 2, 117-118 (1970)

9. Vost, A., Hollenberg, C.H.: Effects of diabetes and insulin on DNA synthesis in rat adipose tissue. Endocrinology 87, 606-610 (1970)

10. Salans, L.B., Zarnowski, M.J., Segel, R.: Effect of insulin upon the cellular character of rat adipose tissue. J. Lipid Res. 13, 616-623 (1972)

11. Angervall, L., Björntorp, P., Martinsson, A.: Lipids in newborn of alloxan-diabetic rats. Diabetes 14 , $724-728(1965)$

12. Picon, L.: Effect of insulin on growth and biochemical composition on the rat fetus. Endocrinology 81, $1419-$ $1421(1967)$

13. Osler, M.: Body fat of newborn infants of diabetic mothers. Acta Endocr. (Kbh.) 34, 277 - 286 (1960)

14. Karlberg, P., Engström, I., Lichtenstein, H., Svennberg, I.: The development of children in a Swedish Urban Community. A prospective longitudinal study. III. Physical growth during the first three years of life. Acta paediat. scand. Suppl. 187, 48 (1968)

15. Hales, C.N., Randle, P.J.: Immunoassay of insulin with insulin antibody precipitate. Lancet $1963 \mathrm{I}, 200$

16. Levin, K., Linde, S.: Determination of glucose in blood, cerebrospinal fluid and urine with a new glucose-oxidase reagent. J. Swed. Med. Ass. 59, 30163036 (1962)

17. Cramér, K., Isaksson, B.: An evaluation of the Theorell method for the determination of total serum cholesterol. Scand. J. clin. Lab. Invest. 11, 213-216 (1959)

18. Carlson, L.A.: Determination of serum glycerides. Acta Soc. Med. upsalien. 64, 208-213 (1959)

19. Moore, F.D., Olesen, K.H., McMurry, J.D., Parker, H.V., Ball, M.R., Boyden, C.M.: The body cell mass and its supporting environment. Philadelphia: Saunders 1963

20. Sköldborn, H., Arvidsson, B., Andersson, M. : A new whole body monitoring laboratory. In: Proceedings of the Sixth International Nordic Meeting on Clinical Physics. Acta radiol. (Stockh.) Suppl. 313, 233 (1972) 
21. Lindholm, B.: Body cell mass during long-term treatment with cortisone and anabolic steroids in asthmatic subjects. Acta Endocr. (Kbh.) 55, 222-239 (1967)

22. Berg, K., Isaksson, B.: Body composition and nutrition of school children with cerebral palsy. In: Berg, K.: Adaption in cerebral palsy of body composition, nutrition and physical working capacity at school age. Acta paediat. scand. Suppl. 204, 41 (1970)

23. Sjöström, L., Björntorp, P., Vrana, J.: Microscopic fat cell size measurements on frozen-cut adipose tissue in comparison with automatic determinations of osmium-fixed fat cells. J. Lipid Res. 12, 521-530 (1971)

24. Hirsch, J., Goldrick, R. B. : Serial studies on the metabolism of human adipose tissue. I. Lipogenesis and free fatty acid uptake and release in small aspirated samples of subcutaneous fat. J. clin. Invest. 43, $1776-1792(1964)$

25. Björntorp, P., Berchtold, P., Tibblin, G.: Insulin secretion in relation to adipose tissue in men. Diabetes $20,65-70$ (1971)

26. Sjöström, L., Smith, U., Krotkiewski, M., Björntorp, P.: Cellularity in different regions of adipose tissue in young men and women. Metabolism 21, 1143-1153 $(1972)$
27. Lindberg, W., Natvig, H., Rygh, A., Svendsen, K.: Høyde og vektundesøkelser hos volksene menn og kvinner. T. norske Laegeforen. 76, 361-368 (1956)

28. Pedersen, J., Osler, M.: Hyperglycemia as the cause of characteristic features of the foetus and newborn of diabetic mothers. Dan. med. Bull. 8, 78-83 (1961)

29. Berglund, G., Björntorp, P., Sjöström, L., Smith, U. The effect of early malnutrition in man on body composition and adipose tissue cellularity at adult age. Acta med. scand., in press (1974)

30. Goldrick, R.B., McLoughlin, G.M.: Lipolysis and lipogenesis from glucose in human fat cells of different sizes. J. clin. Invest. 49, 1213-1223 (1970)

31. Sjöström, L.: Adult human adipose tissue cellularity and metabolism with special reference to obesity and fatty acid synthesis de novo. Acta med. scand. Suppl. $544(1972)$

Dr. U. Smith

Second Medical Service

Sahlgren's Hospital

S-41345 Gothenburg

Sweden 